\title{
Effect of Intellectual Capital on Organizational Sustainability with Employee Innovative Behavior as Intervening Variables in Pt. Jaya Maritime Services
}

\author{
Hilman Najib, Lenny Christina Nawangsari
}

\section{ABSTRACT}

Organizational sustainability is an important strategy to increase organizational capabilities not only to provide economic benefits, but also social and environmental benefits. The reality on the ground is that not all companies really pay attention to the dimensions of sustainability, both in terms of economy / profit, people and the environment. This is because it is considered that the sustainability of the organization is voluntary. Therefore, research is needed on the factors that influence organizational sustainability. The research objective is the effect of intellectual capital on organizational sustainability with innovative employee behavior as an intervening variable at the PT. Jaya Maritime Services. The research method used is explanatory quantitative with SEM-PLS. The sample in this study were 50 employees of PT. Jaya Maritime Services. The sampling technique used in this study was saturated sampling (census). The results showed that human capital and structural capital have a positive and significant effect on innovative behavior, while relational capital has a positive and insignificant effect on innovative behavior, innovative behavior has a positive and significant effect on organizational sustainability, human capital has a negative and insignificant effect on organizational sustainability, structural capital. has a negative and significant effect on organizational sustainability, relational capital has a positive and significant effect on organizational sustainability, innovative behavior mediates the effect of human capital on organizational sustainability, innovative behavior mediates the effect of structural capital on organizational sustainability, and innovative behavior mediates the effect of relational capital on organizational sustainability. Based on the inter-dimensional correlation matrix analysis, to improve employee engagement, it is recommended to maintain and improve indicators: (1) employee expertise in special jobs (specialists); (2) corporate culture content; (3) mutual collaboration skills; (4) developing new ideas, and (5) providing stable salaries for employees.

Keywords: Human Capital, Structural Capital, Relational Capital, Organizational Sustainability.

\section{INTRODUCTION}

The Industrial Revolution 4.0 is said to be able to make the world more sustainable because it not only aims to facilitate company production, but also helps in environmental balancing programs [1]. The Industrial Revolution 4.0 can be a lever to promote inclusive and sustainable industrial development. But at the same time there is a risk of increasing unemployment. This is because many companies consider that increasing profits and protecting the environment are two conflicting goals [2], [3].

Sustainable business starts from the notion of sustainable development which comes from the understanding and belief of the community that nature is very limited. The definition of organizations sustainability refers to the goals of organizations to achieve profit and enhance social development while taking environmental aspects into
Submitted : January 29, 2021

Published : February 18, 2021

ISSN: $2507-1076$

DOI: $10.24018 /$ ejbmr.2021.6.1.714

Hilman Najib

Magister Management, Mercu Buana University, Jakarta, Indonesia. (e-mail: nadjibxxxiii@gmail.com) Lenny Christina Nawangsari * Magister Management, Mercu Buana University, Jakarta, Indonesia.

*Corresponding Author

account [4]. Organizational sustainability is an increase in the ability of business organizations to better understand the surrounding community, customers, employees, shareholders, and offer solutions for special needs that can lead to better cooperation with the organization. [5]. Based on this definition, organizational sustainability is a company's output that needs to be considered properly in order to provide benefits to the company.

In fact, not all companies implement the sustainable development of an organization optimally, both in terms of economy / profit, people, and the environment because it is considered voluntary organizational sustainability. One of them is PT. Jaya Maritime Services (JMS), as a company engaged in the provision of seafaring services for domestic vessels and ocean going vessels. The results of interviews conducted with management regarding the sustainability of the organization show that in terms of profit, in carrying out 
the form of corporate responsibility to society in the economic sector there is no due to the ability of companies that were only established in 2010 and have low profit margins and tend to decline. PT. Jaya Maritime Services (JMS) in 2017 has a profit margin of Rp. 2,623,485,510, then decreased in 2018 with a profit margin of $\mathrm{Rp}$. $326,157,500$, - and again experienced a significant decline in 2019 amounting to -Rp. 1,289,955,629.

This condition shows that the economy is still not optimal. In terms of people, it is known that PT. JMS has carried out various activities and efforts to improve the welfare of employees have not been maximized. Activities that have been carried out as a form of concern for employee development activities only provide remuneration and salary, as well as educational assistance for children, the opportunity to attend training. As the company admits, the implementation has not been maximal due to the company's cash flow. In terms of environment, the company has not implemented sustainability optimally, both internally and externally. Internally, efforts to save on electricity, water, paper, etc., employees are not yet fully aware that they still need to be reminded of the savings so that the company cannot optimize savings and develop better. It is evident that expenses such as the use of electricity, water, paper, and others are still high and volatile. And externally, the company provides assistance or sponsorship if someone submits a proposal, such as from the urban village because there is no CSR.

TABLE I: RECORD OF COSTS PT. JAYA MARITIME SERVICES (JMS) PERIOD 2017-2019 (PERCENTAGE)

\begin{tabular}{|c|c|c|c|}
\hline \multirow{2}{*}{ Information } & \multicolumn{3}{|c|}{ Year } \\
\hline & 2017 & 2018 & 2019 \\
\hline Water costs & Rp 72.188.659 & Rp 66.553.817 & Rp 78.791.920 \\
\hline Electricity cost & Rp 4.292.748 & Rp 5.234.748 & Rp 6.667.373 \\
\hline $\begin{array}{c}\text { Stationery costs } \\
\text { Sponsorship }\end{array}$ & Rp 15.506.000 & Rp 12.262.000 & Rp 17.932.500 \\
\hline $\begin{array}{c}\text { and } \\
\text { environmental } \\
\text { costs }\end{array}$ & Rp 10.750.000 & Rp 13.165.600 & Rp 9.720.148 \\
\hline Total & Rp 102.737.407 & Rp 97.216.165 & Rp 113.111.941 \\
\hline
\end{tabular}

Table 1 shows that the costs for electricity, water, paper / writing utensils, etc. are still high and fluctuate each year and even tend to increase. This means that the level of savings for sustainability purposes is still low. Externally, the company does not have a special budget, meaning that it is temporary according to certain events or conditions, so that environmental conservation efforts are still low.

Based on the description of these problems, it can be explained that the condition of PT Jaya Maritime Service is still not able to implement organizational sustainability. In the economic aspect, it is known that the profit margin in the last 4 years has shown a decline, on the social aspect, concern for employee development activities in the form of increased compensation and capacity building opportunities but following the company's cash flow conditions. Furthermore, in the environmental aspect, the costs of using electricity, water, paper, and other costs have not been optimal in terms of savings and tend to fluctuate.

Regarding the optimal implementation of sustainability, there are several factors that influence, such as human capital, structural capital, and relational capital [4], [6]-[8], employee innovative behavior [9], knowledge sharing [10], green training and development, green performance management and appraisal, and green employee retention [11], dynamics capability, product and/or service, corporate social responsibility, supply chain, informational technology [12].

In this study, the factors that will be examined in influencing organizational sustainability are intellectual capital and innovative behavior. These two factors are a problem that is happening at PT. JMS, which is shown by lack of employee skills, most employees who do not know the company culture, lack of communication skills, and contribute to providing creative ideas shown by employees are also lacking. This is revealed through the results of a survey conducted in December 2020. Based on the description of the problems described, this study examines further the influence of the aspects involved in intellectual capital on organizational sustainability with employee innovative behavior as an intervening variable in the company PT. Jaya Maritime Services.

\section{LITERATURE REVIEW AND HYPOTHESIS DEVELOPMENT}

\section{A. The Influence of Human Capital on Innovative Behavior}

Human capital is an important factor in improving employee innovative behavior [8]. On the other hand, a company whose employees have innovative behavior will help its organization achieve superior economic benefits compared to its competitors [13]. This is because employees are constantly updating existing knowledge to develop new ideas to meet customer needs and satisfaction. The depth and diversity of employees' skills and experiences is a great source of creativity, new knowledge and innovative behavior [14]. The research that has been done proves that there is a significant influence between human capital on innovative behavior [7], [8], [13], [15]. Other studies have found human capital has an effect on innovation [9], [16], performance of radical innovation [14], employee performance [17], and innovation capabilities [18]. Meanwhile, the different results shown also reveal that human capital has no effect on innovation [19].

H1: Human capital has a positive and significant effect on innovative behavior.

\section{B. The Influence of Structural Capital on Innovative Behavior}

Structural capital is an organizational capability that includes infrastructure, information systems, routines, procedures and organizational culture that supports employee efforts to produce optimal intellectuals [9]. The appropriate mechanism of structural capital or organizational capital enables the transformation of individual knowledge to be more innovative. Other studies also prove that there is a significant influence between structural capital on innovative behavior [8]. These results are in line with research which reveals that structural capital has a significant effect on innovative behavior [7], [13]. Other studies have found structural capital has an effect on 
innovation [9], [16], [19], performance of radical innovation [14], employee performance [17], and innovation capabilities [18].

H2: Structural capital has a positive and significant effect on innovative behavior.

\section{The Influence of Relational Capital on Innovative Behavior}

There is an effect of relational capital on employee innovative behavior [8]. These findings indicate that the higher the relational capital, the more innovative employee behavior is. The role of the learning process to gain customer trust can be actualized by the innovative behavior of employees. These results are supported by other research that shows that relational capital has a significant effect on innovative behavior [7], [13]. Other studies have found that relational capital has an effect on innovation [9], [16], [19], performance of radical innovation [14]. Different from other results which explain that relational capital has no effect on innovation capabilities [18].

H3: Relational capital has a positive and significant effect on innovative behavior.

\section{Effect of Innovative Behavior on Organizational Sustainability}

Innovative behavior makes a big contribution to company competition, because innovative behavior is designed to help individuals improve their work abilities and in implementing their ideas. There is a link between innovative behavior and sustainable development because sustainable development requires effort and innovation [20]. Companies whose employees have innovative behavior can help the organization's sustainability [13].

H4: Innovative behavior has a positive and significant effect on organizational sustainability.

\section{E. The Influence of Human Capital on Organizational Sustainability}

Human capital remains a valuable asset to organizations for sustainable business practices [5]. It is further disclosed that human capital has a positive and significant relationship with economic and environmental sustainability [5]. The higher the human capital, the higher the sustainable competitive advantage [2], [6], [10]. Meanwhile, other studies also confirm the link between green human capital and business sustainability [21]. Other studies reveal that green human capital has no effect on business sustainability [21]. However, these results do not mean that organizations should ignore human capital. In fact, human capital is the most important resource that contributes to sustainability. Human capital is seen as a very important element in achieving the right development and achieving sustainability.

H5: Human capital has a positive and significant effect on organizational sustainability.

\section{F. The Influence of Structural Capital on Organizational Sustainability}

A high level of structural capital in a service company indicates a proper organizational culture and a willingness of employees to share knowledge and integrate it in formal structures and systems [6]. Other studies reveal that structural capital is important to achieve sustainability [2]. Likewise, the results of other studies show that green structural capital has a positive and significant effect on business sustainability [21].

H6: Structural capital has a positive and significant effect on organizational sustainability.

\section{G. Effect of Relational Capital on Organizational Sustainability}

Relational capital was found to be an important resource in business operations and sustainability [6]. This explains that the relationship between members and employees in a company that is based on norms of trust and cooperation can help increase knowledge sharing and organizational activities towards better results. This is consistent with the results of research conducted by other studies which reveal that green relational capital affects business sustainability [4], [21]. Both studies believe that a wide network connection is needed to accelerate and improve sustainability.

H7: Relational capital has a positive and significant effect on organizational sustainability.

\section{H. Innovative Behavior Mediates the Influence of Human Capital on Organizational Sustainability}

Employees who have innovative behavior will help their organization achieve superior economic benefits compared to its competitors, which means that human capital will become an intangible asset by the organization that it will keep up with changes and continuously update existing knowledge to develop new ideas to meet customer needs and satisfaction. [13]. The diversity of employee skills and experiences is a great source of creativity, new knowledge, and innovative behavior, so the inability to recruit highquality technical staff can be a serious problem and a constraint on sustainable growth [14]. Therefore, it can be assumed that before employees have a high understanding of organizational sustainability, employees will have innovative behavior first after being influenced by high human capital.

H8: Human capital has a positive and significant effect on organizational sustainability through innovative behavior.

\section{Innovative Behavior Mediates the Influence of Structural Capital on Organizational Sustainability}

Companies with high structural capital can inspire employees to start new ways of thinking, and apply unique ideas to practice [13]. It involves all the structures and processes required by members of the organization to be productive and innovative. The results of other studies reveal that structural capital is important to achieve sustainability [2]. Therefore, from this study, structural capital can influence innovative behavior, thus indirectly affecting organizational sustainability.

H9: Structural capital has a positive and significant effect on organizational sustainability through innovative behavior.

\section{J. Innovative Behavior Mediates the Effect of Relational Capital on Organizational Sustainability}

Relational capital can help companies to not only build 
legitimacy to strengthen and encourage innovative behavior in organizations, but also enable organizations to develop human capital that is superior to other competitors. [13]. Human capital is superior, in this case, the strong relationship between employees in the company by building wide network connections can accelerate and improve organizational sustainability. [21]. Therefore, from this research, relational capital can influence innovative behavior, thus indirectly affecting the sustainability of the organization.

H10: Relational capital has a positive and significant effect on organizational sustainability through innovative behavior.

\section{RESEARCH METHODOLOGY}

This research uses a quantitative approach with explanatory research type (explanation). Explanatory research, which is a type of research that seeks to explain the causal relationship between variables. Relationship is research that is used to determine causal relationships. So in research there are independent variables and dependent variables [22]. The population in this study were all employees of PT. Jaya Maritime Services. The total population of all employees is 50 people. The sampling technique used is total sampling, in which the entire population is sampled. Thus, the sample used in this study were 50 employees of PT. Jaya Maritime Services. The data collection procedure used in this study consisted of a questionnaire, observation, and documentation. The data analysis technique of this research uses the structural equation model (SEM).

\section{RESEARCH RESULT AND DISCUSSION}

The results of descriptive analysis on each research variable are shown in Table 2 below.

The mean value shown by the Human Capital indicator (X1) is 3.76 to 3.94 . This value indicates that in general, the combination of knowledge, skills, innovativeness, attitudes and behavior, and the ability to develop employees is good.

In Structural Capital (X2) the mean value shown by each indicator is in the range of values from 3.86 to 4.08 . These results explain that in general the creative abilities of the organization, such as employee attitudes towards authority and responsibility and awareness of the organization's core culture are good.

The mean value shown by each indicator of the Relational Capital variable (X3) is 3.94 to 4.08 . The mean value explains that in general the ability of employees to build harmonious relationships between the company and the company's external parties is good.

For innovative behavior (Y1), the mean value shown by each indicator is 3.88 to 3.92 . The mean value shown explains that in general employees have new ideas or ideas in good organizations.

In organizational sustainability (Y2), each indicator shows a mean value of 3.86 to 4.04 . These results explain that in general the company strives to achieve profit but still improves social development by taking into account environmental aspects.
The results of the research hypothesis test using SEM PLS that pay attention to the value of the inner model shown.

TABLE 2: DESCRIPTIVE ANALYSIS OF RESEARCH VARIABLES

\begin{tabular}{|c|c|c|}
\hline Variable & Indicator & Mean \\
\hline \multirow{5}{*}{ Human Capital (X1) } & $\mathrm{X} 1.1$ & 3,82 \\
\hline & $\mathrm{X} 1.2$ & 4,08 \\
\hline & $\mathrm{X} 1.3$ & 4,04 \\
\hline & X1.4 & 3,76 \\
\hline & $\mathrm{X} 1.5$ & 4,00 \\
\hline \multirow{5}{*}{ Structural Capital (X2) } & $\mathrm{X} 2.1$ & 3,92 \\
\hline & $\mathrm{X} 2.2$ & 3,94 \\
\hline & $\mathrm{X} 2.3$ & 3,86 \\
\hline & $\mathrm{X} 2.4$ & 3,96 \\
\hline & $X 2.5$ & 3,94 \\
\hline \multirow{4}{*}{$\begin{array}{l}\text { Relational Capital } \\
\text { (X3) }\end{array}$} & X3.1 & 3,94 \\
\hline & $\mathrm{X} 3.2$ & 4,08 \\
\hline & X3.3 & 4,04 \\
\hline & X3.4 & 3,94 \\
\hline \multirow{7}{*}{$\begin{array}{l}\text { Innovative Behavior } \\
\text { (Y1) }\end{array}$} & X3.5 & 4,04 \\
\hline & Y1.1 & 3,90 \\
\hline & Y1.2 & 3,88 \\
\hline & Y1.3 & 3,90 \\
\hline & Y1.4 & 3,84 \\
\hline & Y1.5 & 3,92 \\
\hline & Y1.6 & 3,88 \\
\hline \multirow{10}{*}{$\begin{array}{c}\text { Organizational } \\
\text { Sustainability (Y2) }\end{array}$} & Y2.1 & 3,86 \\
\hline & Y2.2 & 3,94 \\
\hline & Y2.3 & 3,98 \\
\hline & Y2.4 & 4,04 \\
\hline & Y2.5 & 3,94 \\
\hline & Y2.6 & 3,88 \\
\hline & Y2.7 & 4,00 \\
\hline & Y2.8 & 3,86 \\
\hline & Y2.9 & 4,02 \\
\hline & $\mathrm{Y} 2.10$ & 4,02 \\
\hline
\end{tabular}

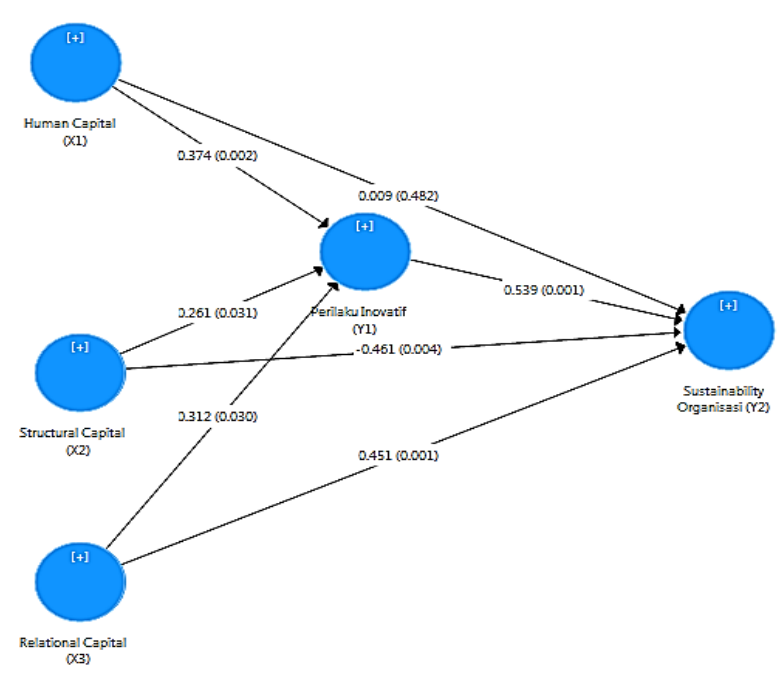

Fig. 1. Results of the Structural Model (Inner Model).

TABLE 3: HyPOTHESIS TEST RESULTS FOR DIRECT EFFECT

\begin{tabular}{|c|c|c|c|c|}
\hline Construct & & $\begin{array}{l}\text { Original } \\
\text { Sample }\end{array}$ & $\begin{array}{c}\mathrm{P}- \\
\text { value }\end{array}$ & Information \\
\hline $\begin{array}{l}\text { Human Capital (X1) -> Innovati } \\
\text { Behavior (Y1) }\end{array}$ & & 0.374 & 0.001 & $\begin{array}{l}\text { Positive, } \\
\text { significant }\end{array}$ \\
\hline $\begin{array}{l}\text { Structural Capital (X2) } \\
\text { Innovative Behavior (Y1) }\end{array}$ & $->$ & 0.261 & 0.026 & $\begin{array}{l}\text { Positive, } \\
\text { significant }\end{array}$ \\
\hline $\begin{array}{l}\text { Relational Capital (X3) } \\
\text { Innovative Behavior (Y1) }\end{array}$ & $\rightarrow$ & 0.312 & 0.024 & $\begin{array}{l}\text { Positive, } \\
\text { significant }\end{array}$ \\
\hline $\begin{array}{l}\text { Innovative Behavior (Y1) } \\
\text { Organizational Sustainability (Y2) }\end{array}$ & $\rightarrow$ & 0.539 & 0.002 & $\begin{array}{l}\text { Positive, } \\
\text { significant }\end{array}$ \\
\hline $\begin{array}{l}\text { Human Capital (X1) -> Organizatio } \\
\text { Sustainability (Y2) }\end{array}$ & nal & 0.009 & 0.480 & $\begin{array}{c}\text { Positive, not } \\
\text { significant }\end{array}$ \\
\hline $\begin{array}{l}\text { Structural Capital (X2) } \\
\text { Organizational Sustainability (Y2) }\end{array}$ & $\rightarrow$ & -0.461 & 0.004 & $\begin{array}{l}\text { Negative, } \\
\text { significant }\end{array}$ \\
\hline $\begin{array}{l}\text { Relational Capital (X3) } \\
\text { Organizational Sustainability (Y2) }\end{array}$ & $\rightarrow$ & 0.451 & 0.001 & $\begin{array}{l}\text { Positive, } \\
\text { significant }\end{array}$ \\
\hline
\end{tabular}


Human capital has a significant positive effect on innovative behavior, as indicated by the original sample value of 0.374 (positive) with a $\mathrm{p}$ value of 0.001 . These results explain that the better the company's Human Capital, the more innovative ability of employees to behave.

Structural capital has a significant positive effect on innovative behavior as indicated by the original sample value of 0.261 (positive) with a $p$ value of 0.026 . These results explain that the better the structural capital of the company, the more innovative ability of employees to behave.

Relational capital has a significant positive effect on innovative behavior as indicated by the original sample value of 0.312 (positive) with a $\mathrm{p}$ value of 0.024 . These results explain that the better the relational capital of the company, the more innovative ability of employees to behave.

Innovative behavior has a significant positive effect on organizational sustainability as indicated by the original sample value of 0.539 (positive) with a p value of 0.002 . These results explain that the higher the employee's innovative behavior, the more the organization's sustainability increases.

Human capital has a positive and insignificant effect on organizational sustainability as indicated by the original sample value of 0.009 (positive) with a p value of 0.480 . These results explain that the better the company's human capital does not guarantee it will affect the sustainability of the organization.

Structural capital has a significant negative effect on organizational sustainability as indicated by the original sample value of -0.461 (negative) with a $\mathrm{p}$ value of 0.004 . These results explain that the better structural capital, the lower the sustainability of the organization.

Relational capital has a positive and significant effect on organizational sustainability as indicated by the original sample value of 0.451 (positive) with a $\mathrm{p}$ value of 0.001 . These results explain that the better the relational capital of the company will increase the sustainability of the organization.

TABLE 4: HYPOTHESIS TEST RESULTS FOR INDIRECT EFFECT

\begin{tabular}{lccc}
\hline \multicolumn{1}{c}{ Construct } & $\begin{array}{c}\text { Path } \\
\text { Coefficient }\end{array}$ & $\begin{array}{c}\text { P- } \\
\text { value }\end{array}$ & Information \\
\hline $\begin{array}{l}\text { Human capital } \rightarrow \text { innovative } \\
\text { behavior } \rightarrow \text { organizational } \\
\text { sustainability }\end{array}$ & 0.210 & 0.014 & $\begin{array}{c}\text { Positive, } \\
\text { significant }\end{array}$ \\
$\begin{array}{l}\text { Structural capital } \rightarrow \text { innovative } \\
\text { behavior } \rightarrow \text { organizational } \\
\text { sustainability } \\
\begin{array}{l}\text { Relational capital } \rightarrow \text { innovative } \\
\text { behavior } \rightarrow \text { organizational } \\
\text { sustainability }\end{array}\end{array}$ & 0.141 & 0.046 & $\begin{array}{c}\text { Positive, } \\
\text { significant }\end{array}$ \\
\hline
\end{tabular}

On the indirect effect, the results of hypothesis testing show that human capital has a significant positive effect on organizational sustainability through innovative behavior as shown by the path coefficient value of 0.210 with a $p$ value of 0.014. In the previous direct effect, it was known that human capital had no significant effect on organizational sustainability. Therefore, it can be explained that innovative behavior does not have a mediating role in the influence of human capital on organizational sustainability.
The result of the indirect effect hypothesis test shows that structural capital has a positive and significant effect on organizational sustainability through innovative behavior as shown by the path coefficient value of 0.141 and a $p$ value of 0.046. These results explain that an increase in the company's structural capital can increase the employee's innovative behavior which then increases the sustainability of the organization.

The results of hypothesis testing also show that relational capital has a positive and significant effect on organizational sustainability through innovative behavior, which is shown by the path coefficient value of 0.168 and a $p$ value of 0.035 . These results explain that the increase in relational capital can increase the innovative behavior of employees which can then increase the sustainability of the organization.

\section{CONCLUSIONS}

The results of the study explain that human capital, structural capital, and relational capital have a significant positive effect on innovative behavior. These results explain that human capital, structural capital, and relational capital have a role in increasing the innovative behavior of company employees.

The results also explain that human capital has no effect on organizational sustainability, while structural capital and relational capital have a significant positive effect on organizational sustainability. These results explain that changes in the value of structural capital and relational capital can increase organizational sustainability.

On the results of the indirect effect, it is known that innovative behavior does not have a mediating role in the influence of human capital on organizational sustainability, but innovative behavior has a mediating role on the effect of structural capital and relational capital on organizational sustainability.

Based on the conclusions that have been explained, the suggestions that can be put forward are: (1) requiring certain divisions in the back office to have skills with the standards required in the Permenhubla and also providing special training to obtain special skills certificates for seafarers; (2) building an organizational climate that is felt positively by employees so as to generate innovative behaviors from unfettered new thoughts and get support from the company; (3) develop training on relationship building so as to create trust, mutual respect, mindfulness, and open communication both internally and externally to the company; (4) helps provide a suitable plan for developing new ideas that employees have and building an understanding of risks; (5) increase salaries or discuss with employees the compensation requested to be relevant to the employees' abilities and pay attention to employee health by providing quality and sustainable drinking water, not temporary in nature.

In practice this research has limitations, including: (1) The object of this research is only at PT. JMS, so that there are opportunities to research objects in different industrial fields; (2) The sample used in this study was only 50 samples; (3) this only limits three exogenous variables, namely human capital, structural capital, relational capital and two endogenous variables, namely innovative behavior 
and organizational sustainability.

\section{REFERENCES}

[1] T. S. Tsalats, "Industri 4.0 Dapat Membuat Dunia Lebih Sustainable," MataMataPolitik, 2019. [Online]. Available: https://www.matamatapolitik.com/industri-40-sustainable-analisispolling/. [Accessed: 29-May-2020].

[2] C. S. Akhtar, K. Ismail, M. A. Ndaliman, J. Hussain, and M. Haider, "Can Intellectual Capital of SMEs Help in Their Sustainability Efforts," J. Manag. Res., vol. 7, no. 2, p. 82, 2015.

[3] S. Monica, "Human Capital and Sustainable Organizations: A Review," Int. J. Sci. Res., vol. 8, no. 7, pp. 792-797, 2019.

[4] M. K. Omar, Y. M. Yusoff, and M. D. K. Zaman, "The Role of Green Intellectual Capital on Business Sustainability,' World Appl. Sci. J., vol. 35, no. 12, pp. 2558-2563, 2017.

[5] E. I. Sunday, "Intellectual Capital and organizational sustainability in manufacturing firms in Rivers," Int. J. Adv. Acad. Res., vol. 3, no. 4, pp. 1-17, 2017.

[6] R. Arshad, N. H. Ab Samad, A. Kamaluddin, and N. Roslan, "Intellectual capital, accountability and sustainability in non-profit organizations," Asian J. Sci. Res., vol. 9, no. 2, pp. 62-70, 2016.

[7] A. Ş. Örnek and S. Ayas, "The Relationship between Intellectual Capital, Innovative Work Behavior and Business Performance Reflection," Procedia - Soc. Behav. Sci., vol. 195, pp. 1387-1395, 2015.

[8] I. Sidharta, M. Sidik Priadana, and A. Affandi, "Innovative behavior: The study of intellectual capital effect on creative fashion industry in Bandung, Indonesia," Probl. Perspect. Manag., vol. 17, no. 4, pp. 404-415, 2019.

[9] A. Elsetouhi, I. Elbeltagi, and M. Y. Haddoud, "Intellectual capital and innovations: Is organisational capital a missing link in the service sector?," Int. J. Innov. Manag., vol. 19, no. 2, 2015.

[10] Widodo and M. A. Shahab, "The model of human capital and knowledge sharing towards sustainable competitive advantages," Probl. Perspect. Manag., vol. 13, no. 4, pp. 124-134, 2015.

[11] N. D. \& Purnama and L. C. Nawangsari, "Pengaruh Green Human Resource Management Terhadap Sustainability Business : Pendekatan Konsep," Pros. Semin. Nas. Peningkatan Mutu Perguru. Tinggi, Univ. Mercu Buana Jakarta, Tanjung Benoa-Bali, 29 Nop. 2019, pp. 32-39, 2019.

[12] M.-S. Tsai, M.-C. Tsai, and C.-C. Chang, "The Direct and Indirect Factors on Affecting Organizational Sustainability," J. Manag. Sustain., vol. 3, no. 4, pp. 67-77, 2013.

[13] C. H. Liu, "Creating competitive advantage: Linking perspectives of organization learning, innovation behavior and intellectual capital," Int. J. Hosp. Manag., vol. 66, pp. 13-23, 2017.

[14] L. Agostini and A. Nosella, "Enhancing Radical Innovation Performance Through Intellectual Capital Components," J. Intellect. Cap., vol. 1, no. 1, pp. 1-23, 2017.

[15] D. F. Rulevy and E. Parahyanti, "Hubungan Psychological Capital Dan Perilaku Kerja Inovatif Di Industri Kreatif: Studi Pada Karyawan Perusahaan Xyz," J. Psikogenes., vol. 4, no. 1, p. 99, 2018.

[16] S. J. M. R. Simarmata, "Pengaruh Intellectual Capital Terhadap Kinerja Non Keuangan Perusahaan,” J. Kesejaht. Sos., vol. 2, no. 02, pp. 180-196, 2018.

[17] Y. Kasmawati, "Human Capital Dan Kinerja Karyawan (Suatu Tinjauan Teoritis)," J. Appl. Bus. Econ., vol. 3, no. 4, pp. 265-280, 2017.

[18] F. M. Saddam and M. Mahfudz, "Pengaruh Modal Manusia, Modal Struktural, Modal Relasional, Terhadap Inovasi Dan Efisiensi Operasional Modal Serta ...," vol. 6, pp. 1-12, 2017.

[19] M. Dost, Y. F. Badir, Z. Ali, and A. Tariq, "The impact of intellectual capital on innovation generation and adoption," $J$. Intellect. Cap., vol. 17, no. 4, pp. 675-695, 2016.

[20] P. Khodakarami and Z. Zakaria, "The relationship between iinovative behavior and sustainable development," Eur. J. Bus. Manag., vol. 7, no. 23, pp. 160-170, 2015.

[21] Y. M. Yusoff, M. K. Omar, M. D. Kamarul Zaman, and S. Samad, "Do all elements of green intellectual capital contribute toward business sustainability? Evidence from the Malaysian context using the Partial Least Squares method," J. Clean. Prod., vol. 234, pp. 626-637, 2019.

[22] U. Silalahi, Metode Penelitian Sosial. Bandung: PT Refika Aditama, 2018. 